\title{
01. Mülteci konulu Türkçe ve çeviri çocuk kitaplarında yer alan empati ögelerinin incelenmesi
}

Ezgi DURSUN'

Bircan EYÜP2

APA: Dursun, E.; Eyüp, B. (2021). Mülteci konulu Türkçe ve çeviri çocuk kitaplarında yer alan empati ögelerinin incelenmesi. RumeliDE Dil ve Edebiyat Araştırmaları Dergisi, (Ö9), 1-18. DOI: 10.29000/rumelide.981488.

“Sadece bir ülke var: yeryüzü. Sadece tek bir ulus var: insanllk. Sadece tek bir kader var: sevgi."

(EUM, s. 28)

$\ddot{0} \mathbf{z}$

Bu çalışmada, mülteci konusunu ele alan Türkçe ve çeviri çocuk kitaplarında empati içeren ögelerin belirlenmesi amaçlanmıştır. Çalışma nitel araştırma yöntemlerinden durum çalışmasına göre tasarlanmıştır. Veriler doküman incelemesi ile toplanmıştır. Çalışmanın veri kaynağını 'Benim adım Mülteci değil', 'evinden uzakta (mülteci)' ve 'Halepli Zeynep' adlı üç çocuk kitabı oluşturmaktadır. Kitaplardan 'Benim adım Mülteci değil' İngilizceden, 'evinden uzakta (mülteci)' ise Felemenkçeden Türkçeye çevrilmiştir. 'Halepli Zeynep' ise Türkçe yazılmış bir kitaptır. Bu üç kitabın seçilmesindeki ana neden, ele aldıkları konunun mülteci konusu olmasıdır. Ayrıca kitapların üçünün de benzer yaş gruplarına hitap etmesi ve yazılı metin yanında resimlerin de bulunması seçilmelerinde belirleyici olmuştur. Verilerin analizi içerik analizi tekniği ile yapılmıştır. Çalışmanın sonucunda, incelenen üç kitapta mülteci konusuna çocukların empatik bir bakış açısıyla bakmasını sağlayabilecek ögelerin farklı şekillerde ve oranlarda yer verildiği belirlenmiştir. 'Benim adım Mülteci değil' ve 'evinden uzakta (mülteci)' adlı kitaplarda metinler içerisinde empatiye yönelik ögelerin yoğun bir şekilde yer aldığı belirlenmiştir. 'Benim adım Mülteci değil' adlı kitapta empati ögelerine sorular aracılığıyla okurun sezmesini sağlayacak şekilde yer verilmiştir. 'evinden uzakta (mülteci)' kitabında ise empatiye dair ögelerin doğrudan verildiği görülmektedir. Ancak 'Halepli Zeynep' adlı kitapta empatiye yönelik ögelerin metin içerisinde oldukça az olduğu belirlenmiştir. Resimler açıdan bakıldığında ise bu üç kitaptan 'Halepli Zeynep'in empati içeren resimler açısından daha zengin olduğu, fakat aynı zamanda çocuğa uygun olmayan resimlerin de kitapta yoğun olduğu belirlenmiştir. Diğer iki kitaptan 'Benim adım Mülteci değil'in resimlerinde empatiye dair bir unsur bulunamazken 'evinden uzakta (mülteci)' ise bir resim tespit edilmiştir.

Anahtar kelimeler: Mülteci, empati, çocuk kitapları, Benim adım Mülteci değil, evinden uzakta (mülteci), Halepli Zeynep

YL, Trabzon Üniversitesi, Lisansüstü Enstitüsü, Türkçe ve Sosyal Bilimler Eğitimi, Türkçe Eğitimi ABD (Trabzon, Türkiye) e.drsn6o@gmail.com, ORCID ID: 0000-0003-2932-0916 [Araştırma makalesi, Makale kaylt tarihi: 26.07.2021-kabul tarihi: 20.06.2021; DOI: 10.29000/rumelide.981488]

2 Dr. Öğr. Üyesi, Trabzon Üniversitesi, Fatih Eğitim Fakültesi, Türkçe ve Sosyal Bilimler Eğitimi, Türkçe Eğitimi ABD (Trabzon, Türkiye), bircaneyup@trabzon.edu.tr, ORCID ID: 0000-0001-8061-1159

Adres | Address

RumeliDE Dil ve Edebiyat Araşturmaları Dergisi Osmanağa Mahallesi, Mürver Çiçeği Sokak, No:14/8 Kadıköy - ÍSTANBUL / TÜRKIYE 34714 e-posta: editor@rumelide.com

RumeliDE Journal of Language and Literature Studies Osmanağa Mahallesi, Mürver Çiçeği Sokak, No:14/8

Kadıköy - ISTANBUL / TURKEY 34714 tel: +90 505 7958124, +90 2167730616

e-mail: editor@rumelide.com phone: +90 5057958124, +90 2167730616 


\title{
Examination of empathy elements in Turkish and translated children's books on refugee
}

\begin{abstract}
In this study, it is aimed to determine the empathic elements in Turkish and translated children's books that deal with the refugee issue. The study was designed according to the case study, one of the qualitative research methods. The data were collected by document analysis. The data source of the study consists of three children's books named 'My name is not a Refugee', 'op te Vlucht' and 'Halepli Zeynep'. Content analysis was used in the analysis of the data. As a result of the study, it was determined that the items that could enable children to look at the refugee issue from an empathetic perspective were included in different forms and ratios in the three books examined. In the books titled 'My name is not Refugee' and 'op te Vlucht', it was determined that elements of empathy are intensively involved in the texts. In the book 'My Name is Not a Refugee', the elements of empathy are included in a way that allows the reader to intuit through questions. In the book 'op te Vlucht', on the other hand, it is seen that the elements of empathy are given directly. However, in the 'Halepli Zeynep', it was determined that the elements of empathy are very few in the text. From a visual point of view, it was seen that 'Halepli Zeynep' is richer in terms of empathic pictures. While there was no element of empathy in the pictures of 'My name is not a Refugee', one picture was found in `op te Vlucht'.
\end{abstract}

Keywords: Refugee, empathy, children's books, My name is not a Refugee, op te Vlucht, Halepli Zeynep

\section{Giriş}

Günümüzün önemli sorunlarından bir olan mülteci konusu tüm dünyayı siyasi, ekonomik, sosyal ve kültürel açlardan etkilemektedir. Pek çok ülke her geçen gün önemi daha da artan ve dünya için ciddi bir meseleye dönüşen bu sorunun farkında ve bu duruma yönelik çeşitli önlemler almaya çalışmaktadır. Mültecilik tek taraflı değerlendirilemeyecek bir konu olması sebebiyle hem mülteciler hem de onların sığındığı ülkelerdeki insanlar açısından ele alınması gerekir. Son yıllarda, çeşitli siyasi problem ve savaşlar nedeniyle pek çok insan ülkesini terk etmek zorunda kalmakta ve hâliyle bu da mülteci sayılarının artışına neden olmaktadır. Özellikle Türkiye, Suriye başta olmak üzere diğer ülkelerden gelen birçok mülteciye sığınak olmaktadır. "Bu göç olayları farklı kültürlerin karşılaşmasına neden olmakta ve farklı kültürlerden gelen insanların bir arada yaşamlarını sürdürme zorunluluğu aynı zamanda uyum ve çatışmaya dair önemli sorunlar gündeme getirmektedir" (Aksoy, 2012, s. 293). Toplumlar gerek devletlerinin politikaları gerekse kendilerinin mültecileri farklı görmesi sebebiyle ülkelerine gelen mültecilere karşı çeşitli tutumlar sergilemektedirler. Erdoğan (2015) çalışmasında Türkiye özelinde, kültürel farklılığa vurgu yapan, ötekileştiren ve Suriyelilerin varlığını 'sorun' olarak niteleyen insanların sayısının son derece yüksek olduğunu tespit etmiştir. Ayrıca 'Suriyeli kardeşlerimiz' yaklaşımının toplumda çok yaygın gözlenemediğini ve bununla birlikte Suriyelilerin 'zulümden kaçan', 'zor durumda olan insanlar' olarak tanımlandığını, ancak "bizlerden birileri" olarak görmeme eğiliminin de dikkat çektiğini belirtmiştir. Bu durum kamuoyu araştırmalarına da yansımaktadır. Genel olarak bakıldığında tutumların ağırlıklı olarak olumsuz yönde olduğu ve ayrıca bu tutumların yetişkin ve çocuklar arasında çok yaygın bir şekilde görüldüğü söylenebilir. Zira okul ortamlarında da bir arada bulunan Türk ve mülteci çocukların birbirlerine karşı olumsuz tutumlara sahip oldukları gözlemlenmektedir. Lâkin öğrenciler arasında ortaya çıkan karşılıklı ırkçı söylemlerin her iki grubu da olumsuz etkilediği görülmektedir (Akdeniz, 2018).

Bu olumsuz tutumların ortaya çıkışında birçok neden görülse de mültecilere karşı olan bakış açısının sadece bunlarla sınırlı kalması bile toplumları empati kurmaktan uzaklaştırmaktadır. Empati olgusunun uzak

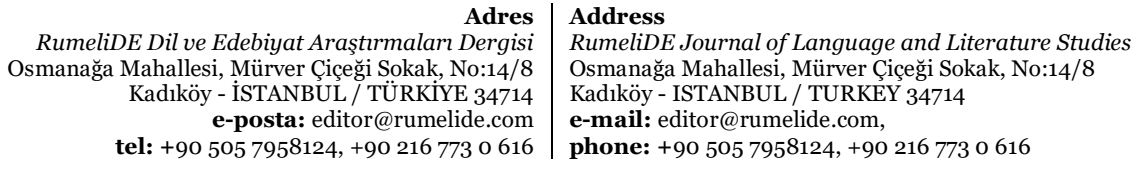


tutulduğu anlayış da yaşanılan konunun tam olarak anlaşılamamasına neden olur. "Empati bireylerin sosyal-duygusal gelişimleri, sorumluluk alma, duyarlı olma, insanların değer ve inançlarını anlamalarında son derece etkili bir beceri olup, sadece kendisiyle empati kurulan kişiye değil, empati kurma sürecindeki kişiye de katkı" (Kaya, 2011, s. 3) sağlar. Empati insanların birbirlerini anlayabilmelerinde ve yaşanılan olayları anlamlandırabilmelerinde kullandıkları önemli iletişim ögelerinden biridir.

"Empati her şeyden önce yalnızlığı çözmektedir. En azından bir an için olsun, empatik anlayış gören kimse, kendinin insan ırkının bir parçası olduğunu hissetmektedir. Açıkça söylenmemiş olsa bile şuna benzer bir deneyim yaşanır. Ben burada, gizli şeylerimi, tuhaf, belki de anormal duygularımı, ne açıça kendimle ne de bir başkası ile konuştuğum duygularımı ifade ediyorum. Buna rağmen o benim duygularımı anlıyor, beni benim anladığımdan daha iyi anlıyor" (Rogers, 1983, s. 114-115).

Yaşamın her alanında empati olgusu ile karşılaşılmaktadır. Mülteci konusu da bu alanlar içerisinde yer almaktadır. Empati, mültecilerin anlaşılmasında ve onlara daha olumlu bir tutum sergilenmesinde önemli rol oynar. Nitekim "empati, toplum bireyleri arasında şefkat tohumları ekerek insanlar arasında merhametin yeșermesine, toplumda birlik ve beraberliğin perçinleșmesine büyük bir katkı sağlar" (Kaya ve Erdem, 2020, s. 83). Yapılan çalışmalarda "empati kurma becerisinin iletişim çatışmalarını engelleyerek daha olumlu ilişkilerin kurulmasını sağladığı, empatinin kendini açma, sosyal duyarlılık, topluma uyum, yardımlaşma ve prososyal davranışları arttırdığı, bunun yanı sıra saldırganlığı ve antisosyal davranışları azaltııı bir rol oynadığı” (Ersoy ve Köşger, 2016, s. 15) görülmektedir.

Toplumda empati becerisinin gelişebilmesi ve yerleşebilmesi için çocuklara bu becerinin küçük yaşta kazandırılması gerekir. Çocuklara empati becerisinin kazandırılması, çocukların etrafındaki olayları daha iyi anlamlandırmalarını ve karşılarındaki insanları ön yargılardan sıyrılarak anlamalarını sağlayacaktır. Empati becerisi yüksek olan çocuklar sosyal ilişki kurma konusunda tercih edilme, kolay iş birliği kurabilme, başkalarına yardım etme, duyarlı olma, uyumlu, sevilen gibi özelliklere sahip iken, empati becerisi düşük olan çocukların akranlarını, öğretmenlerini, ebeveynlerini anlama ve onlarla iletişime geçmede zorluk çekme olasılığı yüksek olacaktır (Yılmaz, 2003). Empati, çocuklara çeşitli yollar ile kazandırılabilir. Öncelikle empati becerisinin kazandırılması için çocuğun belirli bir bilişsel düzeye sahip olması gerekir. Sonrasında ise gerek ebeveyn ve gerekse okul eğitimlerinde empati becerisi çocuğa sezdirilerek kazandırılmalıdır. Bu bakımdan çocuklara empati kazandırmada çocuk edebiyatından yararlanmamak kaçınılmaz bir hâle gelir.

Çocuk edebiyatı öznesi çocuk olan bir edebiyat olması yanında, dilin poetik işlevde kullanıldığı bir edebiyattır. Bir davranışı kazandırmak, bir bilgiyi aktarmak, bir konuda eğitmek ve bir kavramı öğretmek konusunda edebiyat önemli firsatlar sunar (Şimşek ve Yakar, 2016). Çocuk edebiyatı, çocuktaki bu gelişimleri ve değişimleri çocuk edebiyatı ürünleri ile sağlamaktadır. Çocuk edebiyatı ürünleri ile çocuklar yaşamı öğrenmektedir. Yaşamda karşılaşabilecekleri pek çok durumla bu eserlerde karşıllaşarak aslında bir nevi yaşama hazırlanmaktadırlar. Günümüzde mülteci konusu da çocukların yaşamlarında karşıllaşabilecekleri bir durum olduğundan çocuk edebiyatı eserlerinde yerini almaya başlamıştır. Zira "çocuklara; yaşanan insanlık dramını çocukça anlatabilmek, ön yargıların ortadan kalkmasına vesile olup empati becerisini geliştirmek, kültürel duyarlılık oluşturmak ve bunu örtük iletilerle çocuğun çıkarım yapmasına izin vererek yapmak ancak çocuk edebiyatının sunduğu imkânlar neticesinde gerçekleşebilir" (Melanlığlu, 2020a, s. 166). Bu bakımdan çocuğa yönelik eserlerde zor ve dram ağırlıklı bir konu olan mültecilik konusunun sunuluşunda asıl amaç çocukların mültecileri fark etmeleri ve onları anlamalarını sağlamaktır. Bu sebeple çocuk edebiyatı, çocuklarda birçok konunun farkındalığını sağlaması açısından büyük önem arz etmektedir. Bununla birlikte Bradbery (2012) de çocuk edebiyatının, çocukların küresel vatandaş olma bilincini kazanmalarında ve bu bilinci kazanarak çeşitliliğe saygllı olmalarında, değer

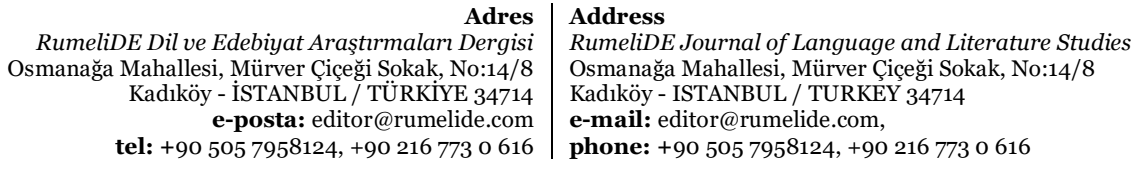


vermelerinde etkili olacağını belirtir. Çocukta bu kazanımların oluşmasında empati ögesinin katkısı göz ardı edilemez. Bundan dolayı mülteci konulu çocuk kitaplarında empati ögesinin sıklıkla yer alması beklenir. Çocuklarda mülteci farkındalığını oluşturmak için kitaplarda empati ögelerine yer verilmesi okurun yaşanılan durumu daha iyi anlamasını, anlamlandırmasını ve olaylara ön yargısız yaklaşmasını sağlayacaktır. Bu bakımdan mülteci konusunu ele alan çocuk kitaplarında okurun empati kurabilmesini sağlayacak ögelere ne sıklıkla ve nasıl yer verildiği de merak konusu olmaktadır. Zira alanyazında da "birinin, ötekini anlama çabasına ortak olma adına bu konuda kaleme alınan çocuk edebiyatı ürünlerini farklı açılardan değerlendiren çalışmalara ihtiyaç duyulmaktadır” (Melanlığlu, 2020a, s. 177).

Alanyazın taramasında, mültecileri konu alan çocuk kitapları üzerine yapılan çalışmaların çok az sayıda olduğu görülmüştür. Yapılan çalışmaların mülteci konusunun farklı açılardan ele aldığı belirlenmiştir. Bulut (2018) mülteci kimliğinin sunuluşu ve mülteci konusunun işlenme biçimlerini incelemiştir. Temur ve Ertem (2019) ele aldıkları mülteci konulu çocuk kitaplarını yapı ve içerik bakımından incelemişlerdir. Savur (2019) çalışmasında mülteci konulu çocuk kitaplarında, zorunlu göçmenlik durumunu kavramlar açısından incelemiş ve ayrıca günümüz Türk çocuk gençlik edebiyatında mülteci temsillerini belirlemiştir. Yakar (2017) ise çalışmasında mülteci konulu iki çocuk kitabında mültecilerin ülkelerinden kaçış sürecini bazı sorular üzerinden incelemiştir. Yine alanyazına bakıldığında Melanlığlu'nun mültecilik konusu üzerine yaptığı çalışmalara rastlanmıştır. Mülteci konulu çocuk kitaplarını duyarlılık açısından ele alan çalışmasının (Melanlığlu, 2020a) yanı sıra göç ve mülteci konulu çocuk kitaplarında mülteci kahramanların yaşadıkları çatışmaları (Melanlıoğlu, 2020b) ve bu kitapları kültürlerarası etkileșim açısından incelediği çalışmaları (Melanlığlu, 2020c) mevcuttur. Araştırmacının bu çalışmasında farklı toplulukların birbirlerini anlaması konusunda kültürel etkileșim ve empatinin önemi üzerinde durduğu görülmektedir (Melanlığlu, 2020c). Genel olarak bakıldığında ise alanyazında mülteci konulu çocuk kitaplarını empati ögeleri açısından inceleyen bir çalışmanın mevcut olmadığı görülmüştür. Oysaki "farklı yaşam durumları ve farklı deneyimler geçiren insanların öykülerine edebiyat aracılığıyla tanıklık etmek mülteci kimliğinin doğru anlaşılmasına ve sürece ilişkin fikir sahibi olunarak empati kurulmasına da olanak" sağlamaktadır (Bulut, 2018). Bunun için mülteci konulu çocuk edebiyatı ürünlerinde empatiye sıklıkla yer verilmesi beklenir. Bu sebeple mülteci konulu çocuk kitaplarında empatinin nasıl kullanıldığı ve ne şekilde empatiye yer verildiği merak uyandıran bir konudur.

Bu çalışmada, mülteci konusunu ele alan Kate Milner'in 'Benim adım Mülteci değil', Pimm van Hest'in 'evinden uzakta (mülteci)' ve Mevlana İdris'in 'Halepli Zeynep' adlı çocuk kitaplarında yer alan empati ögelerinin belirlenmesi amaçlanmıştır.

$\mathrm{Bu}$ amaç doğrultusunda aşağıdaki sorulara cevap aranmıștır:

1. 'Benim adım Mülteci değil', 'evinden uzakta (mülteci)' ve 'Halepli Zeynep' adlı çocuk kitaplarındaki yazılı metinlerde empatiye yönelik ifadeler nelerdir?

2. 'Benim adım Mülteci değil', 'evinden uzakta (mülteci)' ve 'Halepli Zeynep' adlı çocuk kitaplarında yer alan resimlerdeki empati ögeleri nelerdir?

\section{Yöntem}

\section{Araştırmanın modeli}

Bu çalışma nitel bir araştırmadır. Şimşek ve Yıldırım (2008, s. 39) nitel araştırmayı "gözlem görüşme ve doküman analizi gibi nitel veri toplama yöntemlerinin kullanıldığı, algıların ve olayların doğal ortamda

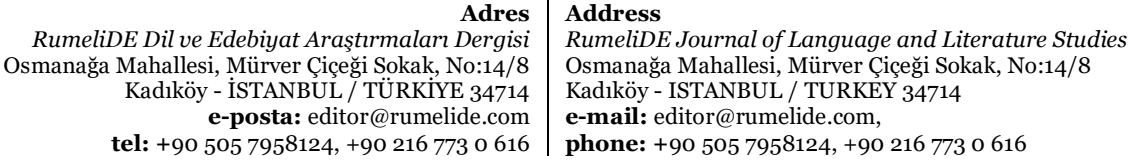


gerçekçi ve bütüncül bir biçimde ortaya konmasına yönelik nitel bir sürecin izlediği bir araştırma" olarak tanımlamıştır. Nitel araştırmacılardan, "değerlendirmeden ziyade daha derinlemesine anlamlar ortaya koyarak yeni fikirler üretmeleri beklenilmektedir. Bu yeni fikirler, yeni sistemler, yeni ürünler, hizmetler ya da süreçler ile ilgili olabilmektedir" (Seggie ve Bayyurt, 2017, s. 19). Bu çalışma nitel araștırma yöntemlerinden durum çalışması olarak tasarlanmıştır. Durum çalışması, sınırlarını araştırmacının belirlediği bir konunun araştırmacı tarafından derinlemesine incelemeye tabii tutulduğu çalışmalardır (Creswell, 2018; Merriam, 2018). Nitekim bu çalışmada da araştırmacılar tarafından konu, çocuk kitaplarında yer alan empati ögeleri ile sınırlandırılmıştır. Sonrasında ise üç kitapta her cümle tek tek okunarak empati içeren ögelerin varlı̆̆ı belirlenmeye çalışılmıștır. Aynı şekilde resimler de araştırmacılar tarafından tek tek incelenmiş ve var olan empati ögeleri belirlenmiştir. Ayrıca durum çalışması daha önce araștırılmayan, inceleyenmeyen olayları, olguları, durumları tespit etmek amacıyla da yapılır (Yin, 1994, s. 147 'den akt. Turhan, Karaca-Turhan ve Baş, 2021, s. 15). Nitekim bu çalışmada da mülteci konulu çocuk kitapları daha önce ele alınmayan empati ögeleri açısından incelenmiştir. Çalışmada verilerin toplanmasında ise doküman incelemesi yöntemi kullanılmıştır. "Doküman incelemesi, araştırılması hedeflenen olgu veya olgular hakkında bilgi içeren yazılı materyallerin analizini kapsar. Doküman incelemesi tek başına bir veri toplama yöntemi olabileceği gibi diğer veri toplama yöntemleri ile birlikte de kullanılabilir" (Yıldırım ve Şimşek, 2018, s. 187).

\section{Veri kaynağı}

Bu çalışmanın veri kaynağı, amaçlı örneklem tekniklerinden ölçüt örnekleme ile belirlenmiştir. Ölçüt "örnekleme yöntemindeki temel anlayış önceden belirlenmiş bir dizi ölçütü karşılayan bütün durumların çalışılmasıdır" (Yıldırım ve Şimşek, 2008, s. 112). Bu çalışmada veri kaynağının belirlenebilmesi için öncelikle alanyazın taraması yapılarak çocuk edebiyatında mültecilik konusunun nasıl ele alındığı ve hangi açllardan değerlendirildiği tespit edilmeye çalışılmıştır. Sonrasında çocuklar ve empati konusuna ilişkin çalışmalar taranmıştır. Bu doğrultuda çalışmanın veri kaynağını oluşturacak olan çocuk kitaplarının belirlenmesinde; mülteci konusunu işleme, yazılı metin ve resim içerme, aynı yaş grubuna yönelik ve farklı dillerde yazılmış olma (Türkçe, İngilizce ve Felemenkçe) ölçütleri dikkate alınmıştır. Kitaplar belirlenirken öncelikle çocuk kitapları yayımlayan yayınevlerinin internet sitelerinde yer alan kitaplar ve daha sonra alanyazında mülteci konusuna yönelik yapılan çalışmalarda ele alınan kitaplar incelenmiştir. Ayrıca internet ortamında mülteci konulu çocuk kitapları üzerine paylaşımlar yapan sayfalar da incelenmiştir. Bu araştırmalar sonucunda çalışma için belirlenen ölçütler doğrultusunda üç çocuk kitabının incelenmesine karar verilmiştir. Çalışmada incelenen kitaplar tablo 1'de gösterilmiștir.

Tablo 1. Çalışmada incelenen kitaplara iliş̧kin bilgiler

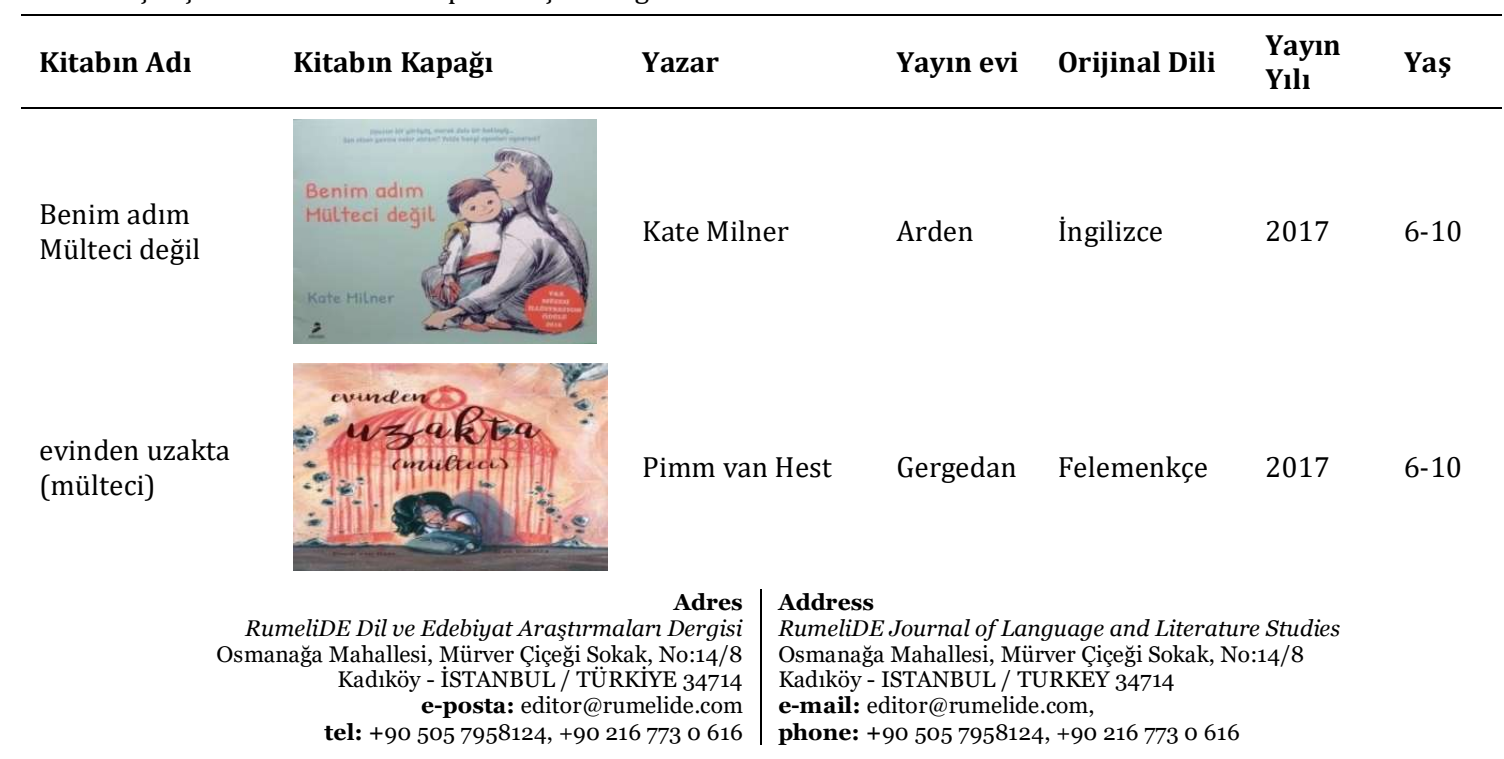




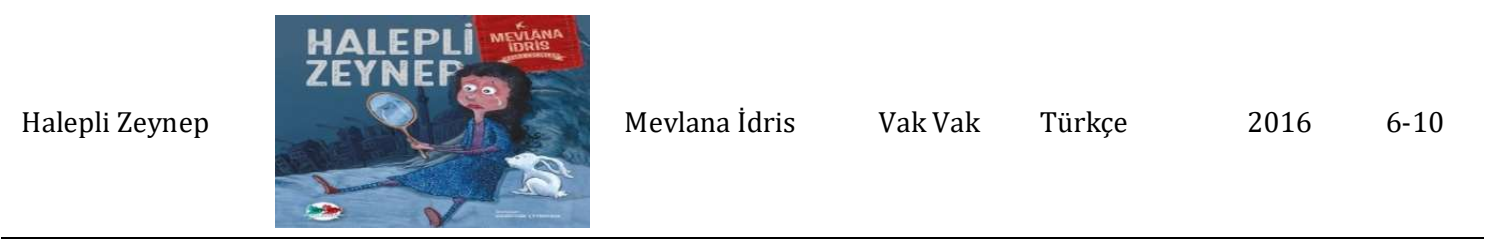

\section{Verilerin toplanması ve analizi}

Çalışmada verilerin toplanma süreci doküman incelemesinde yer alan aşamalar dikkate alınarak şekillendirilmiştir. Süreç; dokümanlara ulaşma, orijinalliği kontrol etme, dokümanları anlama, veriyi analiz etme ve veriyi kullanma olarak beş aşamayı içerir (Forster, 1995'ten akt. Yıldırım ve Şimşek, 2008). Bu çalışmada da ilk aşama olarak çalışmada kullanılacak mülteci konulu çocuk kitapları belirlenip temin edilmiş ve sonrasında ulaşılan çocuk kitaplarının özgünlüğü kontrol edilmiştir. Üçüncü aşamada ise çalıșmada incelenen 'Benim adım Mülteci değil', 'evinden uzakta (mülteci)' ve 'Halepli Zeynep' kitaplarında yer alan ifadeler incelenmiş ve anlamlandırılmaya çalışılmış, ayrıca kitapların nassı inceleneceği belirlenmiştir. Dördüncü aşamada çalışmanın verileri analiz edilmiştir. Verilerin analizinde içerik analizi tekniğinden yararlanılmıştır. "İçerik analizinde temel amaç, toplanan verileri açıklayabilecek kavramlara ve ilişkilere ulaşmaktır” (Yıldırım ve Şimşek, 20o8, s. 227). Bunun için öncelikle kitapların metin ve görsel kısımları birkaç kere okunmuş ve içerisinde yer alan empati ögeleri incelenmeye çalışılmıştır. Çalışmada yer alan kitaplar ilk olarak araştırmacı tarafından incelenmiş sonrasında elde edilen bulgular için bir uzman görüşüne başvurulmuştur. Nitel çalışmalarda uzman görüşü almak çalışmanın güvenirliği ve inandırıcılığı açısından başvurulan stratejilerden biridir (Merriam, 2018). Uzmandan alınan dönütler doğrultusunda bulgulara son şekli verilmiştir. Bulgularda daha anlaşılır olmasına adına kitaplardan yapılan alıntıların sayfa numaraları verilirken 'Benim adım Mülteci değil' BAMD, 'evinden uzakta (mülteci)' EUM ve 'Halepli Zeynep' HZ şeklindeki kısaltmalarıyla verilmiştir.

\section{Bulgular}

\section{‘Benim Adım Mülteci Değil’ kitabında empati içeren ifadeler}

'Benim adım Mülteci değil' kitabında yazar kendi ülkesinden ayrılmak zorunda kalan çocuk kahraman üzerinden göç sürecini aşama aşama anlatmaktadır. Ancak bu anlatma sürecinde tamamen çocuk dili hikâyeye hakîmdir. Amacı olayı dramatize etmek değil, tamamen böyle bir olayın varlığından okuyucuları haberdar etmektir. Çocuk kahraman tüm saflığıyla süreci anlatırken aklına gelen soruları da masumca okuyucuya yönlendirmektedir.

Kitabın başında çocuk kahraman yaşadıkları şehirden ayrılmak zorunda olduğunu belirterek çıkacağı bu yolculuğa “Bunun nasıl bir şey olduğunu anlatayım, ister misin?” (BAMD, s. 3) diyerek okuyucuyu davet eder. Bu soruyla çocuk kahraman doğrudan olmasa da dolaylı olarak okuyucunun kendisi ile empati kurması için ilk adımı atar. Alınan cevabın evet yönünde olduğunu gösterir bir şekilde bundan sonraki süreçte kahraman ben yerine biz ifadesini kullanmaya başlar. Kitapta bu geçiş şöyle sağlanmaktadır: "Bütün arkadaşlarımıza veda etmek zorundayız. Yanına sadece çantanı alabilirsin, ama unutma, yalnızca taşıyabileceğin kadarını doldurmalısın. Sen olsan neler alırdın yanına?” (BAMD, s. 5). Aslında bu ifadelerle okuyucuya da bu hikâyenin bir parçası olduğu hissettirilmektir.

Kitabın başından beri okuyucu hayalî bir arkadaş olarak kahramanın yanındadır ve onunla sohbet eder. Kahraman hayalî arkadașına "Yaşadığımız șehre hoşça kal diyeceğiz. Bu biraz hüzünlü olabilir, ama aynı

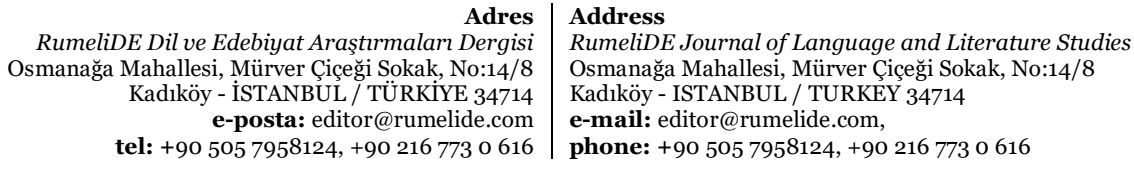


zamanda çok heyecan verici..." (BAMD, s. 6) diyerek çıktıkları yolculuğu anlatmaya devam etmektedir. Sorular bir sohbet havasında kahraman tarafından o anki duruma uygun olacak şekilde okuyucuya sorulur. Şimdi de hayalî arkadaşa çıkılan yolculukta yaşanılan zorlukları hissettirmek amacıyla empati kurmasını sağlayacak bir soru yöneltilir: "Düşünsene, musluklarından su akmayan, çöplerin hiç toplanmadığı bir yerde yaşayabilir misin?” (BAMD, s. 7).

Kahraman kendi durumu ile okuyucunun yaşantısı arasında bağlantı kurmaya çalışır. Aslında kurulan bu bağlantı ile okuyucunun kahramanın yaşadıklarını daha iyi anlaması hedeflenir. Bu kısımda kahraman yolculuğa başladıklarından beri çok uzun süredir yürüdüklerini yine çocukça bir edayla şöyle belirtir: "Rap rap yürüyeceğiz dans edeceğiz ve paten kayacağız sonra koşacağız yine yürüyeceğiz çok çok yürüyeceğiz ve bekleyeceğiz yine bekleyeceğiz çok çok bekleyeceğiz ve yine uyanıp yine yürüyeceğiz daha çok yürüyeceğiz..." (BAMD, s. 7-8). Gerçek hayatta mültecilerin sınırlara ulaşabilmek için çok uzun süre yürüdükleri bilinen bir gerçektir. Fakat kitaptaki anlatımda bu yolculuk, dram ağırlıklı değil eğlenceli bir şekilde sunulur. Yine hayalî arkadaş olan okura "Sen yürüyerek ne kadar uzağa gidebilirsin? (BAMD, s. 8) sorusu yöneltilerek okuyucunun konu üzerine düşünmesi sağlanır. Kitapta genel olarak mülteci konusu üzerine empati, okuyucuya kendi hayatıyla ilgili basit bir sorudan hareketle sezdirilerek yapılmaya çalışılır.

Kitap boyunca yolculuk, hayalî arkadaş ile yaşanılan olaylar ve bunlar üzerine akla gelen çocukça sorular üzerinden devam etmektedir. Yolculuk sonrasında ulaşılan yerde çocuk, hayalî arkadaşı olan okura "Tuhaf bir takım yerlerde uyuyacağız" (BAMD, s. 16) diye belirttikten sonra yine bir soru yöneltir: "Dişlerini nerede firçalarsın? Pantolonunu nerede değiştirirsin?” (BAMD, s. 16). Bu sorularla okurun önce kendi hayatında sahip olduklarını fark etmesi, sonrasında bu imkânların olmadığı durumlarda neler yapabileceği üzerine düșünmesi sağlanır. Böylece mültecilerin bu zorluklarla karşılaștıklarında neler hissettiklerine dair okurun mültecilerle empati kurması amaçlanır.

Geldikleri ülkede konuşulanları anlayamayan çocuk yine hayalî arkadaşı olan okura bu durumu "Hiç anlamadığımız sözcükler duyacağız. Ana dilinden bașka bir dil biliyor musun?” (BAMD, s. 18) diyerek belirtir ve kitabın başından sonuna kadar sorularla kurdurulmaya çalışılan empatiyi devam ettirir. Kahraman artık geldikleri ülkedeki yaşama alışma sürecine geçtiği için ona ilginç gelen olayların hayalî arkadaşına da ilginç geldiğini düşünerek "Tuhaf yemekler tadacağız. Bugüne dek yediğin en tuhaf yemek hangisiydi?" (BAMD, s. 20) sorusunu yöneltir.

Kitabın sonlarına doğru kahraman güvenli bir yere ulaşıldığını belirtir ve yine okura bir soru yönlendirir: "Ne gibi şeyler sana kendi evini hatırlatır?" (BAMD, s. 22). Bu soru ile okurun kendi evi ile arasında kurduğu bağ üzerine düşünmesi sağlanır. Ama aslında okura bir mültecinin de gördüğü ve yaşadığı olaylardan hareketle evini özleyebileceği hissettirilmeye çalışılır. Kitabın sonunda çocuk kahraman yolculuğun sonunu mutlu sona bağlayarak artık gidilen yere yavaş yavaş alışıldığını "Ve kısa bir süre içinde o tuhaf sözcükler anlam kazanmaya başlayacak" (BAMD, s. 23) sözleriyle belirtir.

Çocuk kahraman hem kendisi hem de hayalî arkadaşı okurla çıktıkları bu yolculuğun mutlu sonla bitmesinden memnun olduğunu vurgular. Son olarak hayalî arkadaşı olan okura bir hatırlatma yaparak kitabın vereceği mesaja uygun bir sonla kitabı bitirir. Hayalî arkadaşına ve bizzat kendisine verdiği mesajda her insanın bir ismi olduğunu, toplu bir isimle adlandırılıp önemsiz ve değersizleștirilmesinin doğru olmadığını vurgular ve yazar "Sana mülteci diyecekler ama unutma senin adın mülteci değil" (BAMD, s. 24) diyerek kitabı sonlandırır. Böylelikle yazarın kitabının her sayfasında okurun aynı durumları yaşayan insanları daha iyi anlayabilmesini, onlarla empati kurabilmesini mümkün kılabilecek ifadelere yer verdiği görülmüştür. Ancak bunu yaparken didaktik bir sunumla değil, doğrudan okurun olayın içinde yer almasını

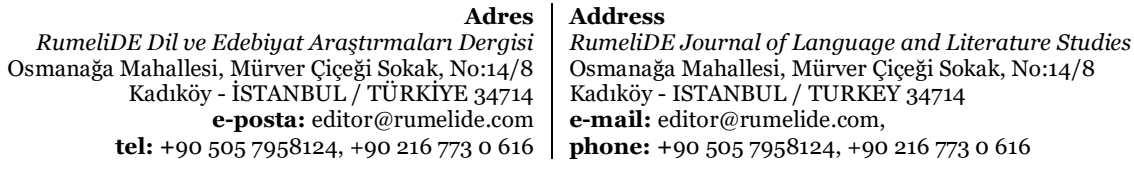


sağlayarak ve bir çocuk kahramanın sorduğu 'çocukça' sorular üzerinden düşünmesini sağlayarak mültecilerle empati kurmasını amaçladığı söylenebilir.

\section{'Evinden Uzakta (Mülteci)' kitabında empati içeren ifadeler}

'evinden uzakta (mülteci)' kitabı yaşanılan yerde çıkan savaş, bu savaş sonrasında çıkılacak yolculuk ve varılan yerdeki olaylar üzerine okura doğrudan empati kurdurmayı amaçlayan bir anlatıma sahiptir. Okur yaşanılan durumun zorluğunu anlayabilsin diye kitapta olaylar ayrıntılarıyla aktarılmaya çalışılmıștır.

'evinden uzakta (mülteci) kitabında ilk sayfadan itibaren okur yaşanılan olayın içine çekilmeye başlanır. Kitabın başında doğrudan okura konu üzerine düşünmesi gerektiği söylenir ve okurun yerine cevap verilir. $\mathrm{Bu}$, ilk sayfada yer alan "Ülkende bir savaş çıktığını düşün! Benim ülkemde mi? Asla! Asla!" (EUM, s. 3) sözleriyle sağlanır. Sonrasında olayın okurun zihninde tam olarak resmedilebilmesi için daha ayrıntılı bir anlatıma gidilir: "Ülkende bir yıkım var... Ülken yangın yeri... Üstelikyardım eden de yok. Köyünde, kasabanda, sokağında, duvarlar bombalanmış... Kendini eksik hissediyorsun. Üzgünsün, korkuyorsun, öfkelisin” (EUM, s. 4). Bu sözlerle okurun duygu durumunu da anlatılan olayla uyumlu hâle getirilmek amaçlandığı söylenebilir.

Kitapta okur doğrudan yaşanılan durumun vahametinden haberdar edilir ve kendisini bu olayın içindeymiş gibi hissetmesi istenir. Sürekli okura "sen" şeklinde hitap edilerek okurun olaydan hiç uzaklaşmaması ve başrolün kendisine ait olduğunu hiç unutmaması sağlanmış olur. Bu şekilde yine okura "Kendini güvende hissettiğin evin paramparça! Ya da düşünsene bir gün aniden evin yok olmuş... Artık ne mutfak, ne de merdivenler var. Artık güvende değilsin..." (EUM, s. 7) diye seslenilerek yaşanılan duruma dâhil edilir.

Kitabın tümüne bakıldığında hemen hemen her sayfada empati ögelerine rastlanmaktadır. Aslında kitabın tek amacının okura mülteci bir çocuğun nasıl durumlarla karşılaştığını ve neler hissettiğini, bizzat kendisini mülteci bir çocuğun yerine koyarak deneyimlemesini sağlamak olduğu söylenebilir. Bunu yaparken gerçek yaşamda mültecilerin yaşadığı tüm zorluklar yansıtılmaya çalıșılmıștır. Kitabın devamında mülteci bir çocuğun isteğini dile getirmek için ve aynı zamanda kitabın başından beri kendini o çocuğun yerine koyan okurun isteğini de dile getirmek amacıyla "Bütün istediğin korkmayacağın bir yaşam, bir yll, bir hafta. Ama önce sadece tek bir gün! Saklanmak, nefesini tutmak, sessiz olmak zorunda kalmadığın tek bir gün! Bütün gün evde kapalı kalmadığın tek bir gün!” (EUM, s. 8-9) cümlelerine yer verilir. Anlama ve anlaşılma çabası ile çıkılan bu yolculuk duygudaşlık ile sürdürülür. Sonrasında mülteci çocuk isteklerini sıralamaya devam eder: "Istediğin sadece okula geri dönmek, herkesi yeniden görmek, sınıfta arkadaşlarınla olmak..." (EUM, s. 11). Bu çerçevede bakıldığınca çocuk mültecinin isteklerinin ne kadar masum ve ne kadar sıradan şeyler olduğu görülmektedir: "Sadece güvenmek, arkadaşlarına güvenmek! Ve bir gün bu savaşın biteceğine inanmak!" (EUM, s. 11). Süreç boyunca empati kuran okur için bu istekler artık kendi istekleri hâlini alır.

Yazar anlatımında çocuk kahramanı daha da belirginleştirmektedir: "Sadece bağıra çağıra şarkı söylemek, alay la lazaya! Sokaklarda oyun oynamak. Futbol, saklambaç, ip atlamak, aynı eskisi gibi..." (EUM, s. 12). Çocuk kahramanı belirginleştirirken bazı bölümlerde geçmişte ve şimdi yaşanılan durumun karşılaștırmaları da görülmektedir: "Bir iki. Bir iki. Durma! Yürü! Yoksa cezanı çekersin. Artık sokaklarda oynamak yok! Açılık, acı ve dikenli teller var” (EUM, s. 13). Böyle hatırlatmalar ile yaşanılan durumda nelerin yapılıp nelerin yapılamadığı vurgulanarak duygudaşlık kuran okura da bu sınırlar bildirilmiștir.

Kitabın başından beri hâkim olan "sen" ifadesinin ülkelerinden kaçmaları gerektiği anda "biz" olarak değiştiği görülmektedir: "Kaçmalıyız! Başka çaremiz yok. Burada kalamayız! Uzaklara gitmeliyiz! Fakat

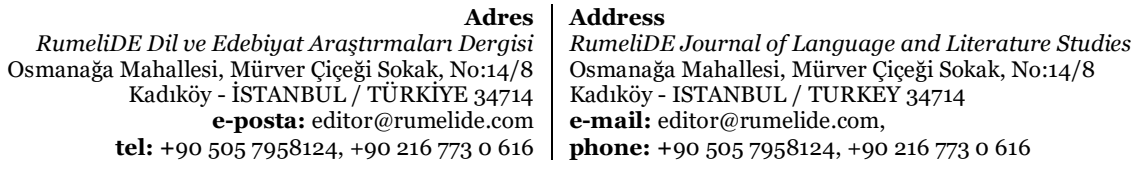


nereye? Nasıl? Kiminle? Nereye kadar? Günlerce mi? Yıllarca mı? Arkadaşlarıma hoşça kal bile demeden mi? Anne, korkuyorum! Baba, korkuyorum!" (EUM, s. 14). Sonrasında ise yolculuğun gerekliliği okura açıklanarak okur da bu yolculuğa ikna edilmektedir: "Artık kalamazsın. Artık, burası senin evin değil. Haydi koş! Çok çok uzaklara koş!” (EUM, s. 17).

Okurun zorlu yolculuğa başlama zamanı gelmiştir. Çıkılacak bu yolculuğun korkutucu olduğu belirtilerek okura bazı tavsiyelerde bulunulmuştur: "Her şeyi biraklyorsun geride... Ama... Ama lütfen oyuncak ayım da gelsin benimle! Sikıca sarıl ona. Sicak tutar o seni. Gecenin ortasinda. Denizin ortasinda...” (EUM, s. 17). Bu kısımda tek başına olan okura, aslında tamamen yalnız olmadığı ve oyuncağının ona güven vereceği belirtilir.

Deniz ortasında geçirilen zorlu yolculuğun sonlandığını ve gidilecek yere varıldığını belirtmek amacı ile "Şimdi her șey bambaşka..." (EUM, s. 18) cümlesine kitapta yer verilmiştir. Yeni gelinen yerde artık okuru farklı durumlar beklemektedir. Kitabın başından itibaren empati kurarak yolculuğu gerçekleștiren okurun farklı bir yerle karşılaşması şöyle anlatılır: "Başka bir ülke, farklı bir dil, farklı insanlar. Yemekleri bile farklı" (EUM, s. 20).

Gerçek hayatta mültecilerin yeni bir ülkeye alışma zorluğunu ve karşılaştıkları olayları kitapta görmek de mümkündür. Kitapta sığınılan ülkedeki insanların mültecilere gösterdikleri tepkilere de yer verilir. Böylelikle okurun mültecilerin maruz kaldığı bu durum üzerine de empati kurması sağlanmış olur: "Sizi aralarına kabul edenler ve etmeyenler... Bazen kollarını açarak, sizi selamlayanlar. Bazen de öfkeli bakışlarla, sizi burada, görmek istemediğini söyleyenler" (EUM, s. 20-21).

Kitapta gidilen yere alışma süreci üzerinde durulduğu görülmektedir: "Ağır ağır, yavaş yavaş, zamanla alışırsın. Yeni bir ülkeye, yeni bir dile, yeni insanlara. Ve yeni insanlar zamanla yeni dostların olurlar" (EUM, s. 23). Yeni gelinen ülkede huzurlu ve mutlu olunduğunun belirtilmesi okurun da empati kurduğu bu zorlu sürecin sonunda huzurlu ve mutlu olmasını sağlamaya yöneliktir: "Ve sen hiç fark etmeden korkun ortadan kaybolur. Ve sen bu yeni ülkede de güneşin parladığını hissedersin" (EUM, s. 24).

Kitabın sonlarına doğru, kendini mülteci bir çocuğun yerine koyan okurun yeni geldiği yeri yadırgamaması ve kendisini yabancı hissetmemesi için yeni ülke hakkında olumlu ifadelere yer verildiğine rastlanmaktadır: "Bu yeni ülkede ne gökyüzü farklıdır aslında ne de güneş ..." (EUM, s. 26). Son olarak kitap başlı̆̆ından hareketle kendisini mülteci yerine koyarak evinden uzakta kalan okura: "Asla! Asla! Asla! Bir daha asla! Evinden uzakta olmayacaksın... Buna hep inan! Sadece inan!" (EUM, s. 26-27) sözleri söylenmiştir. Yazarın, okurun mülteci bir çocukla empati kurmasını sağlarken olaya tüm gerçekliğe ile yaklaştığı görülür. Tüm duyguları okuru üzecek olsa bile açık bir şekilde ifade eder. Ancak olayın sonunda okura mutlu bir tablo çizilir. Buradaki amacı ise olayın başından beri sürece dâhil ettiği, bir mültecinin yaşadıklarını anlamasını istediği okurun tamamen olumsuzluğa kapılmak yerine yine mutlu bir mülteci çocuğun neler hissedebileceğine dair empati kurmasını sağlamak olduğu söylenebilir.

\section{'Halepli Zeynep' kitabında empati içeren ifadeler}

'Halepli Zeynep' kitabında küçük bir kız çocuğu olan Zeynep, ülkesinde çıkan savaştan dolayı babası, annesi ve hayvanları ile birlikte ülkesini terk etmek zorunda kalır. Ülkelerini terk eden Zeynep, ailesi ve hayvanları Gaziantep iline sığınırlar. Burada hep ülkesini düşünen Zeynep çok üzülmektedir. Bu sırada Zeynep bahçede otururken ülkesinde tanıdığı bir köstebek toprağın altından çıkagelir. Köstebek ona ülkesinde olup bitenleri anlatır. Zeynep, köstebek ve diğer hayvanlar aracllığıla ülkesine yardım gönderir. Ülkesini çok özleyen

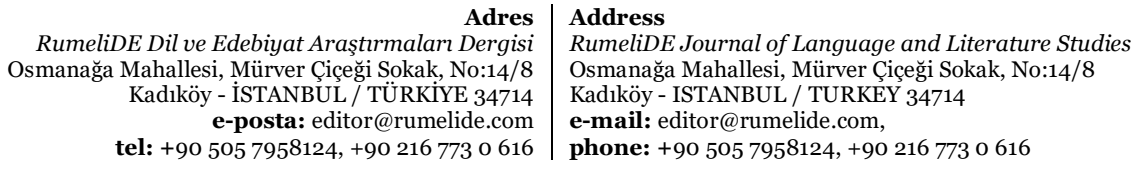


Zeynep, köstebeklerden ona ülkesini hatırlatan şeyleri getirmesini ister. Sonrasında Zeynep siyasilerle görüşür. Onlarla arasında bazı konuşmalar geçer. Kitabın sonunda ise Zeynep'in köstebek ile tanışmasından itibaren tüm bu yaşananların bir rüya olduğu belirtilir.

'Halepli Zeynep' kitabında empati ögelerine çok fazla yer verilmediği belirlenmiştir. Kitapta empati ögeleri daha çok yaşanılan durumlara kahramanların duyguları katılarak verilmeye çalışılmıştır. Kitapta bulunan empati ögelerine yaşanılan savaşın betimlemesi yapılırken kullanılan birkaç cümlede rastlanır: "Atılan bir bombanın ardından artıkyeryüzünden ayrılanlar. Ve geride kalanların büyük, yaralayıcı ağıtları. Keskin, daha çok bir anneden yükselen feryat. Ve sonra günlerce süren, ağaçlara, gökyüzüne, sokaklara, kedilere bile sinen acıll, derin, dışına çıkılamaz bir hüzün. Hüzün" (HZ, s. 9).

Kitapta farklı bir empati şekli olarak hayvanların insanlarla empati kurduğu görülmektedir. Kitapta sıklıkla hayvanların da insanlar gibi bu durumu anlamlandırdığı ve Zeynep ile empati kurduğu belirtilir: "Bazı yıkıntıların yanından geçerken tavşanın camdan iç çekiyor gibi bakındığını düşünüyordu Zeynep" (HZ, s. 10). Yine hayvanların, insanların yaşadıkları olaylara ilişkin kurduğu bir empatiye şöyle yer verilmiştir: "Camdan geriye bakan tavşan, güneşin çoktan doğmuş, birazda yükselmiş olduğunu gördü. Havuç dışında az şeyle ilgilenirdi doğrusu. Şimdiyse kendini her șeyle ilgilenmek zorunda hissediyordu” (HZ, s. 12).

Kitapta başkahraman Zeynep ile onu anlayan herkesin -annesinin, babasının, hayvanlarının- hatta doğanın bile empati kurduğu onun duygularına ortak olduğu ve onu desteklediği anlatılmıștır: "Beyaz tavuğu, tavşanı, bahçesi, annesi, babası ve küçük bahçedeki bazı ağaçlar bile! Zeynep’in yanındaydı” (HZ, s. 13). Burada yazar insan ve hayvanların yanı sıra doğanın da Zeynep'in yanında durduğunu, onu anlayabildiğini ve onunla empati kurduğunu göstermektedir. Yazarın burada insanla, insan dışındaki varlıkların da çok daha iyi empati kurabileceğini vurgulamaya çalıştığı söylenebilir.

Zeynep Halep'ten geldikten sonra sürekli ülkesini düşünür. Oradaki yaşamı hakkında kendisine sürekli sorular sorar. Orada bıraktıkları insanlar hakkında düșünüp onlarla empati kurar: "Oradaki arkadaşları acaba ne yapıyorlardı? SSehirden sessizce ayrıldıkları gün boyunca Zeynep'i göremediklerinde ne düşünmüşlerdi? Komşu arkadaşı Fatma ve Ali, sinıfındaki Meryem, Mahmut, İsmail, Ayșe, Hatice, Hasan şimdi ne yapıyordu? En önemlisi hayatta miydılar? Çünkü televizyondaki haberlerden her an ateşlenen silahlar ve uçaklardan atılan varil bombalarını izlemekten fena olmuştu" (HZ, s. 15). Diğer kitaplarda görülen soru üzerinden empati kurdurma yöntemine bu kitapta da başvurulmuştur. Kitapta, Zeynep'in anlamlandıramadığı savaş ve diğer olaylar okura soru olarak yönlendirilir. Bu sayede okurun bu konular üzerine düşünmesi sağlanır: "Neden sürekli bomba atıllyordu ki insanların, hayvanların, ağaçların üstüne? Biraz bekleseler zaten herkes ölmeyecek miydi?" (HZ, s. 13).

Kitapta Zeynep'in köstebek aracılığı ile Halep'teki çocuklara yardım etmesine yer verilir. Bu anlatımda okurun da Zeynep gibi elinden bir şeyler gelebileceği üzerine düşünmesi sağlanır: “Antep'teki küçük bahçe Halep için lojistik merkezi gibi olmuştu. Zeynep, köstebeklerden aldığı haberlerle Halep'in nabzını elinde tutuyordu. Silahları susturamıyordu, varil bombalarını durduramıyordu ama yine de bir șeyler yapıyordu iște" (HZ, s. 21). Halep'in önceki hâli ve savaş sonrasında geldiği hâle yer verilerek okurun dikkati bu konu üzerine çekilmiş ve kendi hayatı üzerine düşünerek yaşanılan durumun vahametini anlamlandırması sağlanır: "Bir zamanlar burasını cıvll cıvıl yapan insanlar, o telaşlı kalabalık nasıl da dağılmıştı. Gök nasıl da kararmıştı.” (HZ, 21). Zeynep'in köstebeklerden Halep'e duyduğu özlemi giderebilmek için Halep'in suyunu, havasını istemesine yer verilmiştir. Burada okura vatandan ayrı kalındığında yaşanılan özlemin ne kadar zor olduğunu çağrıştıracak ögelere yer verilerek bir an olsun vatanından ayrı kalmanın yaşatacağı durumu hissetmesi amaçlanır: "Halep'in suyunu istedi Zeynep. Su geldi. Halep'in havasını istedi Zeynep. Hava geldi.

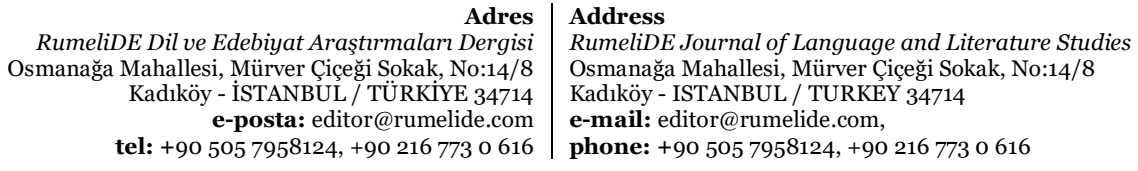


Her şey gelebilir miydi?” (HZ, 25). Sonrasında kitapta Zeynep'in bazı siyasilerle görüşmesine yer verilir. Kitabın sonunda ise Zeynep'in tüm bu gördüklerinin rüya olduğu belirtilir.

Yazar kitapta okurdan ziyade doğrudan karakterler üzerinden empati ögelerine yer verir. Özellikle Zeynep'in kendisinin diğer insanlarla empati kurduğu görülür. Yine diğer kitaplardan farklı olarak insan dışı canlıların da mülteci bir kız çocuğuyla empati kurmasını göstermesi önemli bir bulgudur. Ancak diğer kitaplardan önemli bir farkı ise bu kitapta siyasi kimliklere de fazlasıyla yer verilmesidir. Bu da kitabın siyasi bir mesaj verme amacı taşıdığını da göstermektedir. Bu sebeple çocuğa göre ilkesinin dışına çıkıldığı görülür.

\section{Kitaplarda bulunan resimlerdeki empati ögeleri}

Çalışmada incelenen 'Benim adım Mülteci değil' kitabının resimlerinde empati içeren ögelere yer verilmediği belirlenmiştir. İncelenen ikinci kitap olan 'evinden uzakta (mülteci)' kitabında ise sadece bir resimde empati içeren ögelere yer verildiği görülmüştür. Resimde bir tarafta küçük çocuğa yardım eden insanlar varken diğer tarafta çocuğu istemeyen ve ona kötü bir şekilde bakan insanlar görülmektedir. Bu resimde "kabul edilme" ve "reddedilme" üzerinde durulduğu görülmektedir. Okurun da bu resimden hareketle kendisini hangi kesimde gördüğü düşündürülmeye çalışıldığı söylenebilir. Ayrıca kitapta okur kendisini çocuk kahramanın yerine koyduğu için kendisine nasıl davranılmasını istediği üzerine de kurulmuş bir resim empati ögesi taşımaktadır.

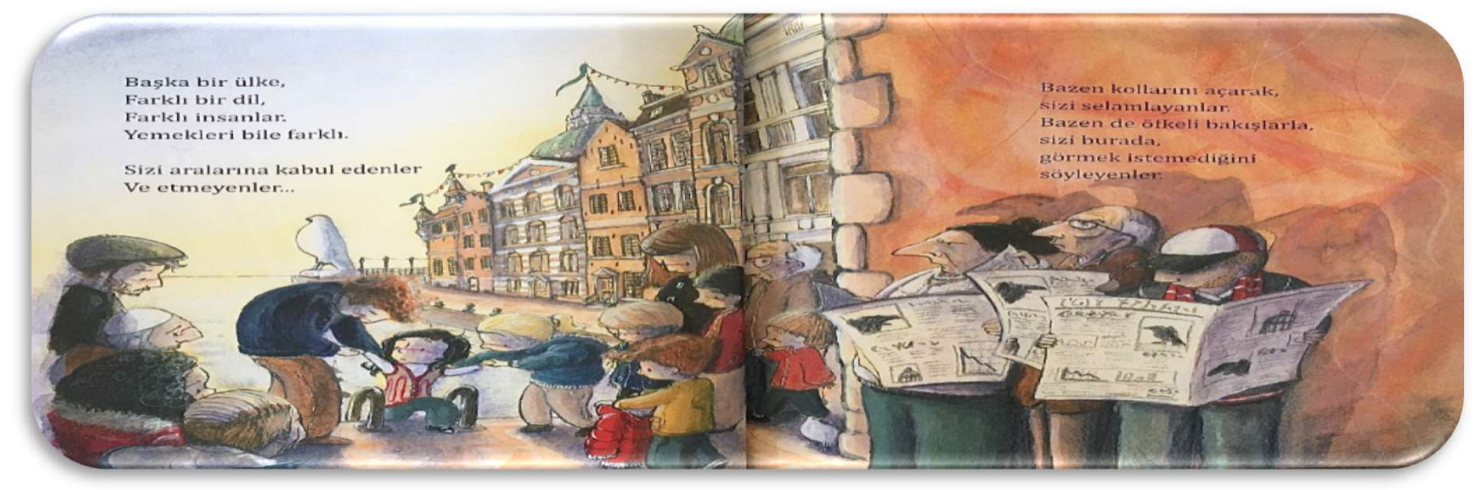

Resim 1. evinden uzakta (mülteci)

'Halepli Zeynep' adlı çocuk kitabında diğer kitaplara oranla daha fazla empati ögesi içeren resimlerin olduğu belirlenmiştir. Kitapta yer alan resimlerde kitabın başkahramanı Zeynep'in hayvanlarının kendisi ile sıklıkla empati kurduğu görülmektedir. Resim 2'de savaşın ilk çıktığı zamanda üzülen ve ağlayan Zeynep ile beraber tavuk ve tavşanın da ağladığı görülmektedir. Burada insanların üzüntüsü ile empati kuran ve bunu hisseden hayvanlara yer verilmiştir. Resim 3'te ise toprağın altından çıkan köstebeğe şaşıran Zeynep ile birlikte yine onun duygularına ortaklık eden onunla empati kuran tavuk ve tavşana yer verilmiştir.

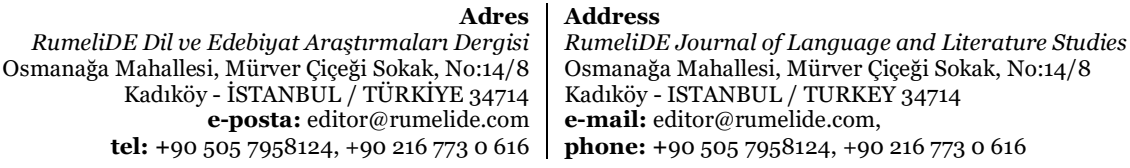




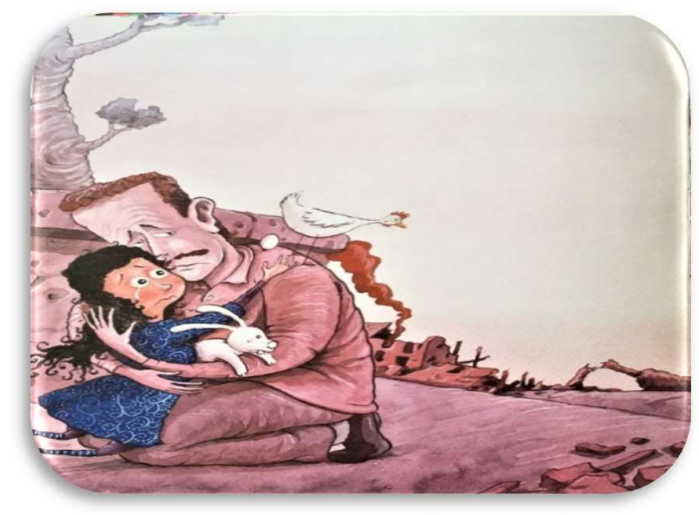

Resim 2. Halepli Zeynep

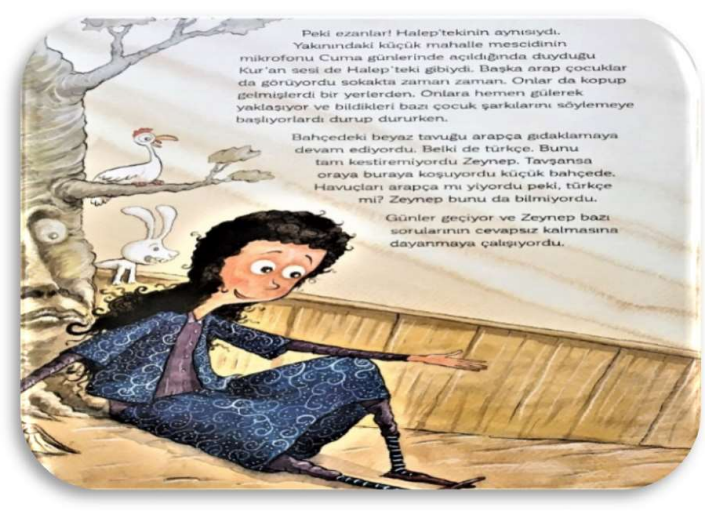

Resim 3. Halepli Zeynep

Kitapta doğanın da Zeynep ile empati kurduğu görülmektedir. Resimde ağlayan Zeynep ile arkasındaki ağacın da ağlayarak Zeynep'in duygularını hissetttiği gösterilmiştir.

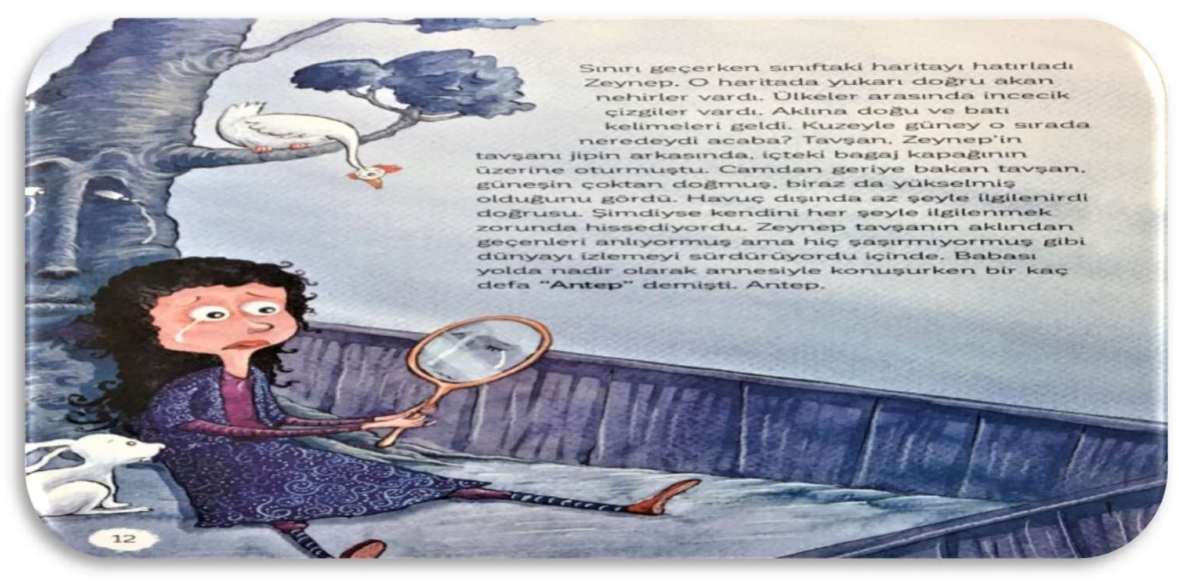

Resim 4. Halepli Zeynep

Kitap içerisinde Zeynep karakterinin bazı siyasi kişilerle görüştüğü bölümler de bulunmaktadır. Resimlerde bu bölümlere de yer verilmiștir. Burada Zeynep'in savaşın sorumlusu olarak gördüğü siyasetçiye kızgın bir şekilde bir şeyler söylediği gösterilirken Zeynep ile beraber kolundaki tavuk, omuzundaki tavşan ve yerdeki köstebeğin de sinirlendiği görülmektedir. Yine bu da hayvanların Zeynep ile empati kurduğu resimlere örnektir. Ayrıca kitapta kırmızı renk ağırlıklı bir şekilde kullanılmıştır. Savaşın vahameti sadece metin kısmına değil resimlere de yansıtılmıştır. Görsellerde savaş, ölüm ve kanı simgeleyen ögeler bolca yer almaktadır.

RumeliDE Dil ve Edebiyat Araşttrmaları Dergisi Osmanağa Mahallesi, Mürver Çiçeği Sokak, No:14/8 Kadıköy - ISTANBUL / TÜRKIYE 34714 e-posta: editor@rumelide.com tel: $+905057958124,+902167730616$
Address

RumeliDE Journal of Language and Literature Studies Osmanağa Mahallesi, Mürver Çiçeği Sokak, No:14/8

Kadıköy - ISTANBUL / TURKEY 34714

e-mail: editor@rumelide.com

phone: +90 $5057958124,+902167730616$ 


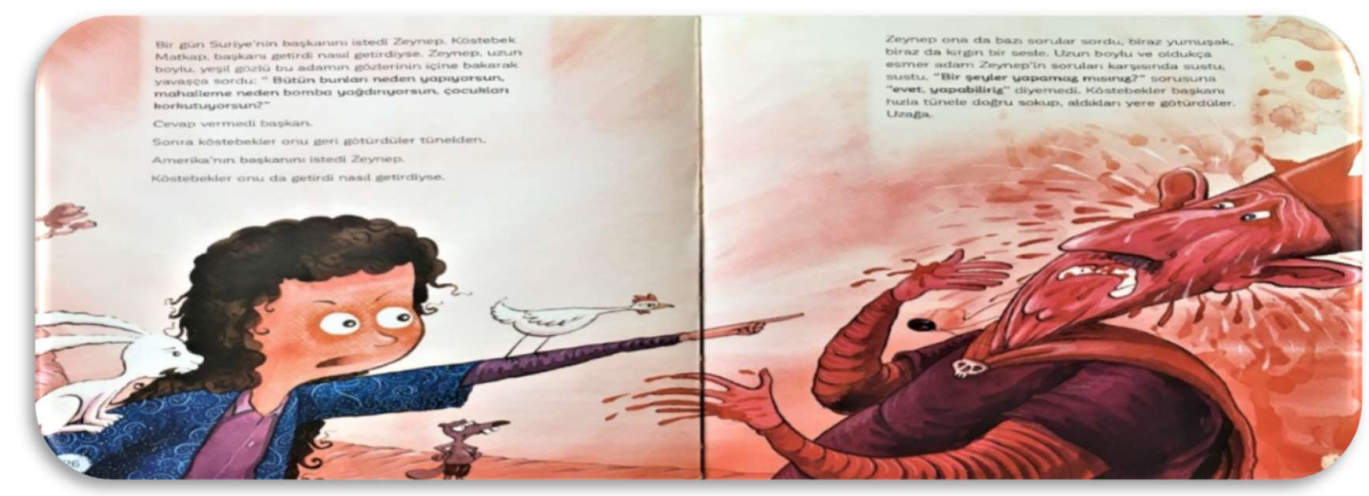

Resim 5. Halepli Zeynep

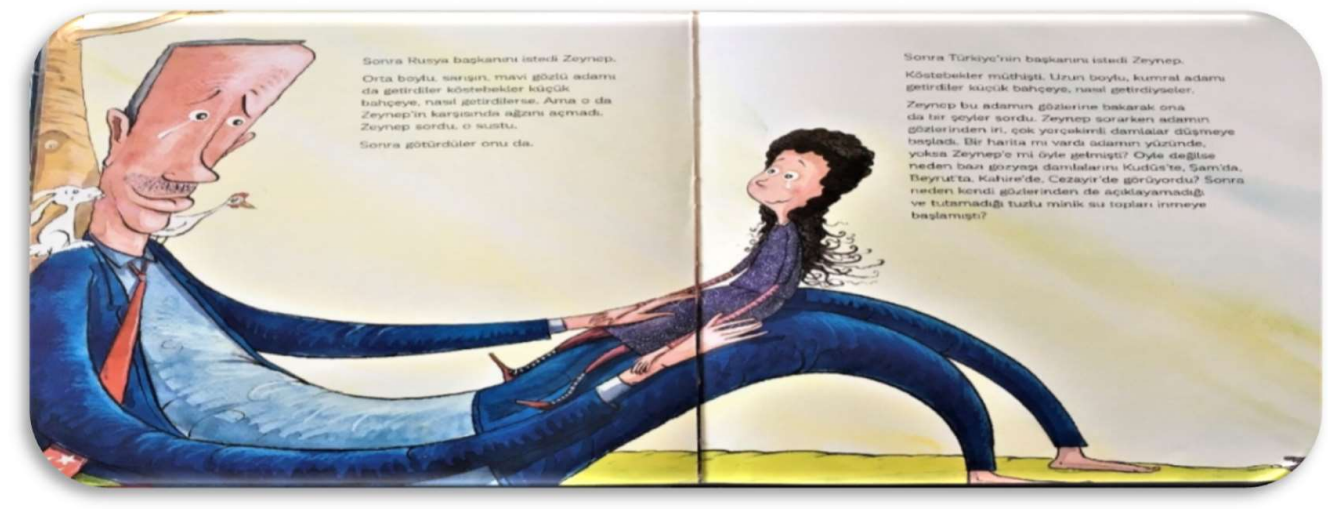

Resim 6. Halepli Zeynep

'Halepli Zeynep' kitabında empati içeren resimlere sıklıkla yer verilirken aynı zamanda olumsuz örneklere de sıkça yer verildiği görülmüştür. Resim 5'te mülteci çocuğun kendi ülkesinin liderine kızdığının gösterildiği resimde hayvanların da Zeynep'le aynı hisleri paylaştıkları görülür, ancak liderin resmediliş şekli çocuğa yönelik bir kitap için hiç uygun değildir. Resim 6'da yine Türkiye Cumhuriyeti'nin Cumhurbaşkanının da Zeynep ile empati kurarak ağladığı görülür. Fakat bir çocuk kitabında siyasi kimliklerden bahsedilmesi ve kişilerin resmedilerek gösterilmesi, siyasi kimliklerden üzerinden mesaj verilmeye çalışılması çocuğa görelik ilkesinin göz ardı edildiğini göstermektedir.

\section{Tartışma ve sonuç}

$\mathrm{Bu}$ çalışmada mülteci konusunu ele alan, yazının ve resmin bir arada kullanıldığı Kate Milner'in 'Benim adım Mülteci değil', Pimm van Hest'in 'evinden uzakta (mülteci)' ve Mevlana İdris'e ait 'Halepli Zeynep' adlı çocuk kitaplarında yer alan empati ögeleri belirlenmeye çalışılmıştır. Bu amaçla kitaplardaki yazılı metinler ve resimler empati ögesi bulundurma açısından incelenmiştir.

Çalışmada, 'Benim adım Mülteci değil' kitabında yer alan metinlerde sıklıkla empati ögelerinin bulunduğu, ancak resimlerde empati ögelerinin bulunmadığı belirlenmiştir. 'evinden uzakta (mülteci)' kitabında ise baştn sona empati kurdurmaya yönelik bir kurgunun olduğu görülmüștür. Bu kitabın resimlerine bakıldığında ise sadece bir resimde empati ögesine rastlanılmıştır. Ancak 'Halepli Zeynep' kitabında yazılı metne bakıldığında diğer kitaplara oranla empati ögelerine çok az yer verildiği tespit edilmiştir. Fakat bu kitabın resimlerinde diğer kitaplardan daha fazla empati ögesinin yer aldığı görülmüştür.

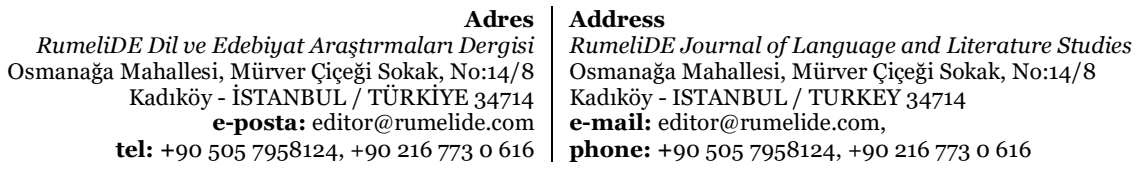


'Benim adım Mülteci değil' kitabında okura mülteci konusu üzerine empati kurdurmanın dolaylı bir şekilde yapıldığı belirlenmiştir. Kitapta okur adeta hayalî bir arkadaş gibi yolculuk boyunca kahramanla beraberdir. Kitabın başında okur bu yolcuğa bir soru ile davet edilmiş ve okurdan alınan cevabın "evet" yönünde olduğunu gösterir bir șekilde yolculuğa çlkılmıştır. Yolculuk boyunca hayalî arkadaş olan okur tüm durumdan haberdar edilmiş ve ayrıca yine sorularla yaşanılan olaylar üzerine neler düşündügü, neler hissettiği ve böyle bir durumda olduğunda neler yapacağı sorulmuştur. Bu sorularla asıl amaç okura dolaylı bir şekilde mülteci konusunu sezdirmek, okurda mülteci farkındalığını oluşturmak ve okurun mültecilerle empati kurmasını sağlamak olduğu söylenebilir. Kitapta bu farkındalığı oluştururken anlatıma çocukça bir dilin hâkim olduğu ve okura yönlendirilen soruların da oldukça masum sorular olduğu görülmüștür. Yaşanılan olay ne kadar dram ağırlıklı olsa da kitapta bu durum eğlenceli bir şekilde, kahraman ve hayalî arkadaş olan okur arasında geçen bir sohbetmiş gibi sunulmuştur. Kitabın kurgusal dünyasında da çocukların sevdiği oyun, dans, paten kaymak gibi ögelere yer verilmesi, konunun çocuklara sunumunda çocukça bir bakış açısının korunduğunu ve hep canlı tutulduğunu göstermektedir. Bu sayede okurda mülteci farkındalığı oluşturulurken okurun bu konudan korkması ve uzaklaşması değil, zor bir durumun farkındalı̆̆ını eğlenceli bir serüvenle fark etmesi sağlanmaktadır. Zira aksi yapılmış olsaydı çocuk okurun empati kurması çok daha zor olabilirdi ve psikolojik olarak da kendini daha kötü hissetmesine sebep olabilirdi diye düşünülmektedir. Bu bakımdan kitap çocuk okurun yaşını da dikkate alarak konuyu çok fazla acıklı hâle getirmeden ancak tüm gerçekliğiyle sunar. Ancak burada dikkat çeken nokta yazarın mülteci konusunda okurun farkındalık kazanmasını ve mültecilerle empati kurmasını sağlarken mümkün olduğunca didaktik bir anlatımdan uzak durmaya çalışmasıdır. Çocuğun kendisinin sorular aracılığıyla fark etmesini, düşünmesini, anlamasını ve empati kurmasını amaçladığı görülmektedir.

'evinden uzakta (mülteci)' kitabında ise ilk sayfadan itibaren okura doğrudan 'sen' ifadesi yöneltilir ve bu hikâyenin başkahramanının da kendisi olduğu hissettirilir. Böylece okur doğrudan hikâyenin içine çekilir ve mültecilerle empati kurması amaçlanır. 'Benim adım Mülteci değil' adlı kitapta başkaraman tarafından okur yolculuğa davet edilirken bu kitapta okurun doğrudan hikâyenin başkahramanı yapıldığı görülür. Okur için gereken ortam, düşünce ve duygular yazar tarafından sayfa sayfa sunulmuş, okura sadece kendisini bu hikâyeye ait hissetmek kalmıştır. 'Benim adım Mülteci değil' adlı kitapta mültecilerin yaşadığı olumsuzluklara doğrudan yer verilmeyip çocukça bir bakış açısıyla konu ele alınmıştır. Bu kitapta ise mültecilerin yaşamış oldukları tüm olumsuzluklar, zorluklar, mücadeleler metne yansıtılmış ve hikâyede çocukça bir dilden, bakış açısından ziyade keskin bir anlatım hâkimdir. Okurun her sayfada tüm gerçekliği ile sunulan olayların içinde olması mültecilerle çok daha kolay empati kurmasını sağlayabilir niteliktedir. Ancak bu gerçekliğin 6 ila 10 yaş arasına hitap eden bu kitabın okurlarını derinden etkileyebileceği düşünülebilir. Lâkin kitabın sonunda yeni bir ülkede, yeni arkadaşlarla başlayan serüvenle yazar kitabın başından beri hep olumsuzluklara maruz kalan okurun olumsuz düşüncelerden kurtularak kitabı bitirmesini amaçlandığını söyleyebiliriz.

'Benim adım Mülteci değil' ve 'evinden uzakta (mülteci)' kitaplarının yazılı metinlerinde okurun empati kurmasını sağlayacak ögelere çok sıkça yer verildiği tespit edilirken 'Halepli Zeynep' adlı kitapta okurun empati kurmasını sağlayacak ögelere çok az yer verildiği belirlenmiştir. 'Halepli Zeynep' kitabında yazar metni kurgularken okura herhangi bir görev vermez. Diğer iki kitapta yazarlar okuru olayın içine doğrudan çekerken ‘Halepli Zeynep’te ise bunu neredeyse hiç görmeyiz. Çocuk okur, kitabı okurken sadece okuyucu konumundadır. Kitapta baştan sonra mülteci bir kızın yaşadıkları anlatılırken okurun doğrudan empati kurmasını amaçlayan ögelere çok fazla yer verilmediği görülür. Ancak kitabın başkahramanı Zeynep'in ülkesindeki insanlarla, arkadaşlarıyla empati kurduğunu gösteren ifadelere kitapta yer verilmiştir. Böylece bu kitapta doğrudan empati kuran kişi kitabın başkahramanı Zeynep'tir. İncelenen diğer iki kitapta ise bu duruma rastlanılmaz. 'Halepli Zeynep' kitabını diğer iki kitaptan ayıran diğer önemli bir nokta ise

Adres Address

RumeliDE Dil ve Edebiyat Araştırmaları Dergisi $\quad$ RumeliDE Journal of Language and Literature Studies

Osmanağa Mahallesi, Mürver Çiçeği Sokak, No:14/8 Osmanağa Mahallesi, Mürver Çiçeği Sokak, No:14/8

Kadıköy - İSTANBUL / TÜRKIYE 34714 Kadıköy - ISTANBUL / TURKEY 34714

e-posta: editor@rumelide.com e-mail: editor@rumelide.com,

tel: +90 505 7958124, +90 2167730616 phone: +90 505 7958124, +90 2167730616 
hayvanların ve ağaçların da Zeynep'le empati kurmasıdır. İnsan dışı canlı varlıkların da yaşanan acılara kayıtsız kalamadığı, acı çeken bir çocuğun hisselerini çok iyi anlayabildiği ve onunla empati kurabildiği kitapta sunulmaktadır. Zeynep mutlu olduğunda mutlu olan, ağladığında ağlayan, kızdığını kızan tavuk, tavşan, ağaç gibi canlılar kitapta yer almıştır. 'Halepli Zeynep' kitabının dikkat çeken bir yönü ise hikâye içerisinde siyasi karakterlere de yer verilmesidir. Zeynep, terk etmek zorunda kaldığı ülkesinin devlet başkanına kızarken geldiği ülkenin cumhurbaşkanı ile güzel bir sohbet içerisinde sunulur. Cumhurbaşkanın Zeynep'le empati kurduğunu gösteren ifadelere yer verilir. İncelenen diğer iki çeviri kitapta ise çocuk kahramanlar ya çocuklarladır ya da hayalî arkadaşlarıyladır (okurun kendisi) ve siyasi karakterlere hiç yer verilmemiştir. Bu da 'Halepli Zeynep' kitabının siyasi mesaj vermeye yönelik kaygılarla yazıldığı şeklinde yorumlanabilir. Çocuk kitabının ve özellikle böyle hassas bir konunun siyasi kimlikler üzerinden sunulmuş olması bir çocuk kitabı açısından olumsuz bir durum olarak değerlendirilebilir. Nitekim Aytekin (2016) de çocuk edebiyatı yazarlarının eserlerinde siyasi düşüncelerini okurlara empoze etmemeleri gerektiğini vurgular. Bu sebeple çocuk kitaplarının yayınevleri tarafından çocuğu merkeze alarak hassasiyetle incelenmesi ve çocuklar için uygun olanlarının basılmasının önemi ortaya çıkmaktadır.

Araştırmada ayrıca ele alınan kitapların resimlerindeki empati ögeleri de incelenmiştir. Zira incelenen üç kitabın her sayfasında resim yer almaktadır. İncelemeler sonucunda 'Benim adım Mülteci değil' kitabının resimlerinde empati ögelerine yer verilmediği belirlenmiştir. 'evinden uzakta (mülteci)' kitabında ise sadece bir resimde empati ögesine yer verildiği görülmüștür. Ancak bu resimde hem empati kuran hem de empati kurmayan, mültecileri dışlayan karakterlerin bir arada resmedildiği görülmüștür. Bu resim aracılı̆̆ıyla aslında okur empati kuran ve kurmayan insanları daha somut bir şekilde görme ve belki de hangi grup gibi olmayı istediği konusunda da bir tercih yapma imkânı bulmaktadır denilebilir. 'Halepli Zeynep' kitabının resimlerinde ise diğer iki kitaba kıyasla daha fazla empati içeren ögenin yer aldığ belirlenmiştir. Resimlerde başkahraman Zeynep'in duygularını insan dışındaki canlı varlıkların da hissedip aynı duyguları paylaştıkları resmedilerek empati ögelerine yer verilmiştir. Başkahraman ağladığında ağlayan, şaşırdığında şaşıran ve kızdığında kızan hayvanlar ve bir ağaç resmedilmiştir. Fakat yine 'Halepli Zeynep' kitabının resimlerinde çocuğa uygun olmayan birçok olumsuz unsur da tespit edilmiştir. Kitabın resimlerinde kırmızı renk hâkimdir ve görsellerde savaș, ölüm, yıkım tüm gerçekliğiyle yansıtılmıştır. Ayrıca yazılı metinde yer verilen siyasi karakterlerin kimler olduğunun kitapta açıça resmedildiği görülmüştür. Bu siyasi karakterler günümüzün devlet başkanlarıdır. Özellikle resimlerde de Türkiye Cumhuriyeti Cumhurbaşkanının Zeynep'le duygularını paylaştığını, empati kurduğunu gösteren ögeler mevcuttur.

Sonuç olarak biri Türkçe, ikisi çeviri olan üç kitapta da çocuk okurlara mültecilerle empati kurabilmelerini sağlayabilecek ögelere yer verildiği görülmüştür. Ancak bu ögeler çeviri kitaplarında daha çok metin üzerinden sunulurken Türkçe kitapta görseller üzerinden gerçekleştirilmiştir. Yine çeviri kitaplarda çocuk okurun mültecilerle empati kurması doğrudan okuru olayın içine dâhil ederek, sanki okurun da o maceranın bir kişisiymiş gibi hissetmesi ile sağlanırken Türkçe kitapta böyle bir amacın olmadığı görülmektedir. Resimler açısından bakıldığında ise 'Halepli Zeynep' kitabının resimlerinde empati ögeleri çok daha fazla iken çeviri kitaplar için bunu söylemek mümkün değildir. Fakat bu kitabın da resim içeriklerinde empati ögelerinin yanı sıra olumsuz ögelerin de sıkça kullanıldığı tespit edilmiştir. Ayrıca 'Benim adım Mülteci değil' ve 'evimden uzakta (mülteci)' kitaplarında okura doğrudan bir mesaj verme çabası yoktur, ancak olayların sunuluş biçimi okuru doğrudan mültecilerle empati kurmaya yönlendirmektedir. Lâkin 'Halepli Zeynep' kitabında yaşanılan dehşet anlatılırken mülteci bir çocuk üzerinden siyasi mesaj verme kaygısının ön plana çıktığı görülmüştür. Oysaki çocuk kitaplarının özellikle bu tür mesajlardan uzak durması beklenir. $\mathrm{Bu}$ bakımdan mülteci konusunu ele alan Türkçe ve çeviri çocuk kitaplarında empati içeren ögelerin sunumlarında belirgin farklılık olduğu söylenebilir. Bu doğrultuda mülteci konusunu ele alan yazarların ve

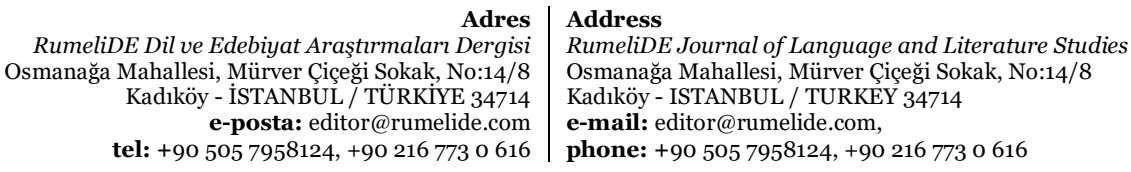


bu kitapların yayımlanmasında önemli rol oynayan yayınevlerinin bu konuya çok daha hassas yaklaşması gerekmektedir. Çocuk kitaplarının çocuğa yönelik olduğunu dikkate alarak bu kitaplarda siyasi mesajlar vermekten uzak durulmalıdır. Ayrıca mülteci çocuklarla her ortamda karşılaşma imkânı bulunan günümüz çocuklarına yönelik yazılacak olan bu tür kitaplarda, konunun daha hassas ele alınması ve çocukların mülteci arkadaşlarıyla empati kurabilmelerine katkı sağlayacak ögelere yer verilmesi oldukça önemlidir. Nitekim bu anlayışla hazırlanan çocuk kitapları, çocuklarmızın empati kurabilme becerilerini her anlamda geliştirmelerine de katkı sağlayacaktır. 


\section{Kaynakça}

Akdeniz, Y. (2018). Türkiye'de yaşayan Suriyeli mülteci öğrencilerin uyum sorunları: Şanlıurfa ili örneği (Yayımlanmamış Yüksek Lisans Tezi). Sakarya Üniversitesi, Eğitim Bilimleri Enstitüsü, Sakarya.

Aksoy, Z. (2012). Uluslararası göç ve kültürlerarası iletişim. Uluslararası Sosyal Araştırmalar Dergisi, 5(20), 292-303.

Aytekin, H. (2016). Çocuk ve gençlik edebiyatında siyasi söylemlere eleştirel bir bakış. Turkish StudiesInternational Periodical For The Languages, Literature and History of Turkish or Turkic, 11(15), 4962.

Bradbery, D. (2012). Using Children's Literature to Build Concepts of Teaching About Global Citizenship. Australian Association for Research in Education and Asia-Pacific Educational Research Association Conference. (NJ1), 1-7.

Bulut, S. (2018). Çocuk edebiyatına sığınanlar: zorunlu göç öyküleri. OPUS Uluslararası Toplum Araştırmaları Dergisi, 8 (14) , 383-410.

Creswell, J. W. (2018). Nitel araştırma yöntemleri-beş yaklaşıma göre nitel araştırma ve araştırma deseni (3. bs). (M. Bütün ve S. B. Demir Çev. Ed.). Ankara: Siyasal Kitabevi.

Erdoğan, M. M. (2014). Türkiye'deki Suriyeliler: Toplumsal Kabul ve Uyum Araştırması, Hacettepe Üniversitesi Göç ve Siyaset Araştırmaları Merkezi, Ankara.

Ersoy, E. G. ve Köşger, F. (2016). Empati: tanımı ve önemi. Osmangazi Tıp Dergisi, 38 (2), 9-17. doi: http://dx.doi.org/10.20515/otd.33993

Hest, P. V. (2017). evinden uzakta (mülteci) (Çev. Ö. Akdik İşli). Ankara: Gergedan Yayınları.

İdris, M. (2016). Halepli Zeynep. İstanbul: Vak Vak.

Kaya, M. ve Erdem, İ. (2020). Çocuk edebiyatı eserlerinin 7. sınıf öğrencilerinin empati becerisinin gelişimine etkisi. Yüzüncü Yıl Üniversitesi Eğitim Fakültesi Dergisi, 17 (1) , 79-114.

Kaya, N. B. (2011). Sosyal bilgiler dersi (4. ve 5. sınıf) öğretim materyallerinde empati becerisinin amaç, kapsam ve etkinlik boyutlarından incelenmesi (Yayımlanmamış Yüksek Lisans Tezi). Marmara Üniversitesi, Eğitim Bilimleri Enstitüsü, İstanbul.

Melanlığlu, D. (2020a). Çocuk edebiyatındaki kayıp mültecilerin izinde duyarlılık eğitimi. Journal of Turkology, 30(1) , 161-179.

Melanlıŏglu, D. (2020b). Çocuk edebiyatında mülteci kahramanların yaşadıkları çatışmalar üzerine bir inceleme. Uluslararası Türkçe Edebiyat Kültür Eğitim (TEKE) Dergisi, 9 (2) , 665-691.

Melanlığlu, D. (2020c). Kardeş veya yük: mülteci çocuk kahramanların bakış açısıyla kültürlerarası etkileşim. Rumeli'de Dil ve Edebiyat Araştırmaları Dergisi , (20) , 95-115.

Merriam, S. B. (2018). Nitel Araştırma: Desen ve Uygulama İçin Bir Rehber (3. bs.). (S. Turan Çev. Ed.). Ankara: Nobel Yayıncllı.

Milner, K. ( 2019 ). Benim adım Mülteci değil. (Çev. A. Turhan) İstanbul: Arden.

Rogers, C. (1983). Empatik olmak değeri anlaşılmamış bir varoluş seklidir. (Çev. F. Akkoyun) Ankara Üniversitesi Eğitim Bilimleri Fakültesi Dergisi, 16 (1), 103-124.

Savur, S. (2019). Günümüz Türk çocuk ve gençlik edebiyatında mülteci sorunu (Yayımlanmamış Yüksek Lisans Tezi). İstanbul 29 Mayıs Üniversitesi, Sosyal Bilimler Enstitüsü, İstanbul.

Seggie, F. N. ve Bayyurt, Y. (Ed.) (2017). Nitel Araştırma Yöntem, Teknik, Analiz ve Yaklaşımlar. Ankara: Anı.

Şimşek, T. ve Yakar, Y. (2016). Çocuk ve Edebiyat. T. Şimşek (Ed.). Kuramdan Uygulamaya Çocuk Edebiyatı, Ankara: Grafiker.

Temur, M. ve Ertem, İ. (2019). Çocuk edebiyatında göç ve göçmenlik. Nevşehir Hacı Bektaş Veli Üniversitesi SBE Dergisi, 9 (2) , 451-466.

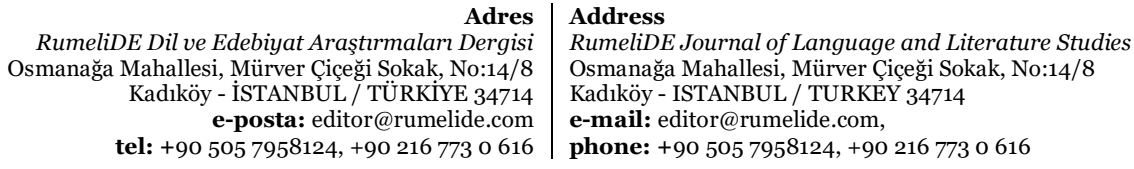


Turhan, O., Karaca-Turhan, F. ve Baş, B. (2021). Türk çocuk edebiyatında meslekler ve toplumsal cinsiyet. Çukurova Üniversitesi Eğitim Fakültesi Dergisi, 50(1), 1-30.

Yakar, Y. (2017). Türk çocuk edebiyatında göç olgusu. Atatürk Üniversitesi Türkiyat Araştırmaları Enstitüsü Dergisi , (58), 339-353

Yılmaz, A. Y. (2003). Empati eğitim programının ilköğretim öğrencilerinin empatik becerilerine etkisi (Yayımlanmamış Doktora Tezi). Ankara Üniversitesi Eğitim Bilimleri Enstitüsü, Ankara.

Yıldırım, A. ve Şimşek, H. (2008). Sosyal Bilimlerde Nitel Araştırma Yöntemleri (11. Baskı). Ankara: Seçkin.

Adres
RumeliDE Dil ve Edebiyat Araşttrmaları Dergisi Osmanağa Mahallesi, Mürver Çiçeği Sokak, No:14/8 Kadıköy - İSTANBUL / TÜRKIYE 34714 e-posta: editor@rumelide.com tel: +90 $5057958124,+902167730616$
Address

RumeliDE Journal of Language and Literature Studies Osmanağa Mahallesi, Mürver Çiçeği Sokak, No:14/8

Kadıköy - ISTANBUL / TURKEY 34714

e-mail: editor@rumelide.com

phone: +90 505 7958124, +90 2167730616 